\title{
Keterampilan Sosial Menjaga Kesejahteraan Psikologis Pengguna Internet ${ }^{1}$
}

\author{
Indah Nugraini \& Neila Ramdhani \\ Fakultas Psikologi Universitas Gadjah Mada Yogyakarta
}

\begin{abstract}
This study aims to examine the role of social skills in mediating the relationship between excessive Internet use and psychological wellbeing. Participants of this study was 206 adolescents aged 16-24 years (87 men, 119 women). Internet Addiction, Social Skills, and Psychological Wellbeing Scales were used to measure these variables. Simple regression analysis indicates that excessive Internet use is a predictor of psychological wellbeing $(b=-0.1774, p<0.05)$, also of social skills $(b=-0.314, p<0.01)$. However, the role of excessive Internet use were decreased even close to zero when regression of this variable with psychological wellbeing were done by including social skills. Excessive Internet use predicted lower psychological wellbeing of the individuals with low socially skilled. Thus, it can be concluded that the social skills is a mediator variable of excessive Internet use relationships and psychological wellbeing.
\end{abstract}

Keywords: mediation, internet addiction, psychological wellbeing, social skills

\begin{abstract}
Abstrak. Penelitian ini bertujuan untuk menguji peran keterampilan sosial dalam memediasi hubungan antara penggunaan internet berlebihan dengan kesejahteraan psikologis remaja. Partisipan penelitian ini adalah 206 remaja berusia 16-24 tahun (87 lakilaki, 119 perempuan). Skala Adiksi Internet, Skala Keterampilan Sosial, dan Skala Kesejahteraan Psikologis yang digunakan untuk mengukur ketiga variabel penelitian sudah memenuhi standar psikometri. Dengan prosedur pengujian variabel mediator, analisis regresi menunjukkan bahwa penggunaan internet berlebihan merupakan prediktor bagi kesejahteraan psikologis $(b=-0,1774 ; \mathrm{p}<0,05)$ maupun keterampilan sosial $(b=-0,314 ; p<0,01)$. Peran penggunaan internet berlebihan ini menurun bahkan mendekati nol ketika regresinya dengan kesejahteraan psikologis dilakukan dengan mengikutsertakan keterampilan sosial. Penggunaan internet berlebihan memrediksi rendahnya kesejahteraan psikologis pada individu yang kurang terampil sosial. Dengan demikian disimpulkan bahwa keterampilan sosial merupakan variabel mediator dari hubungan penggunaan internet berlebihan dengan kesejahteraan psikologis.
\end{abstract}

Kata kunci: adiksi internet, kesejahteraan psikologis, keterampilan sosial, mediator

\footnotetext{
1 Tulisan ini didasarkan pada Skripsi penulis pertama di bawah bimbingan penulis kedua pada Program Studi Sarjana Fakultas Psikologi Universitas Gadjah Mada. Koresponden untuk tulisan ini ditujukan kepada: neila_psi@ugm.ac.id

2 Dosen pada Fakultas Psikologi Universitas Gadjah Mada
} 


\section{NUGRAINI \& RAMDHANI}

Jika pada awal tahun 2000-an sebagian besar remaja mengakses internet di warung internet namun mulai periode tahun 2010-an akses internet sudah semakin meluas (Wahid, Ramdhani, \& Wiradhany, 2014). Survey terakhir yang dilakukan Asosiasi Pengusaha Jaringan Internet Indonesia (APJII) masih menunjukkan pertumbuhan jumlah pengguna internet di Indonesia, 18,4\% dari pengguna adalah remaja (APJII, 2016) dengan mayoritas (97,4\%) dari aktivitas yang dilakukannya ketika berinternet adalah berinteraksi melalui media sosial. Bagi remaja, penggunaan media sosial memfasilitasi mereka berkomunikasi lebih mudah dan cepat. Selama ini remaja pengguna internet harus bertemu muka untuk terhubung dengan teman-temannya, saat ini di kala istirahat sekolah atau di rumah, mereka lebih memilih berkomunikasi melalui media-media sosial yang tersedia. Disamping media sosial, survei yang dilakukan APJII tersebut juga mencantumkan bahwa hiburan yang paling banyak diakses adalah film (41\%), mendengarkan musik $(35,5 \%)$, dan aktivitas lain termasuk di dalamnya menonton olah raga secara daring. Dengan tingginya penggunaan media sosial dan alat-alat hiburan daring ini keinginan dan kesempatan untuk berinteraksi tatap muka berkurang.

Tingginya aktivitas remaja dengan internet ini menimbulkan dugaan bahwa remaja lebih banyak menghabiskan waktu beraktivitas sendirian dengan monitornya sehingga kurang mengembangkan hubungan yang berkualitas dengan orang lain. Dugaan ini bertolak belakang dengan salah satu aspek pembentuk kesejahteraan psikologis yaitu hubungan sosial yang berkualitas (Ryff \& Keyes, 1995). Bahkan, tingginya frekuensi penggunaan internet ini diprediksi dapat mengganggu kesejah- teraan psikologis (Gross, Juvonen, \& Gable, 2002), potensial merasakan kesepian daripada yang mereka rasakan sebelum menjadi pengguna internet dan mengalami kesulitan berhubungan dengan teman sebaya (Esen, Aktas, \& Tuncer, 2013).

Media teknologi serta konten media memiliki dua sisi yang berbeda, ibarat pisau bermata dua (Rodman \& Fry, 2009), di satu sisi internet memberikan manfaat bagi penggunanya seperti memberikan kemudahan dalam mencari informasi, berhubungan dengan teman, memberikan hiburan melaui game, video, dan mendengarkan musik. Di sisi lain ada fenomena lain yang ditimbulkannya bila digunakan berlebihan dan tidak terkendali seperti misalnya gambling, videogames, pornografi, dan perilaku merugikan lainnya (Griffiths \& Wood, 2000).

Beberapa kondisi yang dapat dikategorikan ke dalam dampak negatif adalah penggunaan media sosial pada waktuwaktu yang kurang tepat, misalnya pada jam kerja atau jam belajar. Fenomena lain yang semakin banyak dirasakan terkait dengan penggunaan internet yang tidak tepat adalah menurunnya toleransi terhadap 'hak' atau 'privasi' orang lain dan menurunnya batas antara hal-hal yang pantas dan tidak pantas dilakukan. Contoh dari perubahan ini adalah berkurangnya rasa hormat terhadap orang lain, acuh tak acuh pada saat pengguna internet terlibat di dalam percakapan namun mereka tetap disibukkan dengan gadgetnya, tidak sungkan bila berkomunikasi secara terbuka dengan orang-orang yang tak dikenal, mengunggah foto atau video yang kadang-kadang tidak 'layak' ditampilkan di publik, menulis artikel yang melecehkan agama, adat istiadat, dan tradisi (El Khouli, 2013). 
Beberapa peneliti sudah melaporkan bahwa remaja yang banyak menggunakan internet merasa kurang puas serta merasa memiliki banyak masalah di dalam hidupnya, seperti sering merasa sedih, merasa tidak bahagia, dan sering merasa bosan (Rideout, Foehr, \& Roberts, 2010). Perasaan negatif yang dirasakan ini menghambat proses pencapaian kondisi psikologis yang seimbang. Dengan merasa sedih dan mudah bosan, remaja kurang memiliki sikap positif terhadap dirinya sendiri yang sebetulnya sangat dibutuhkan untuk memperluas hubungan sosial, belajar menetapkan dan mencapai tujuan hidup dalam menentukan arah karir dan pengembangan diri pribadi (Ryff \& Keyes, 1995).

Permasalahan penggunaan internet berlebihan menjadi fokus di dalam tulisan ini. Beberapa ahli menggunakan istilah yang berbeda, misalnya problematic internet use (Shapira et al., 2003) atau internet addiction (Block, 2008; Widyanto \& McMurran, 2004; Young, 2004). Kedua istilah ini memberikan ciri-ciri perilaku yang walaupun berbeda sudut pandang namun mengandung intensi kepada perilaku yang sama, yaitu penggunaan internet yang berlebihan. Dengan mempertimbangkan ulasan tentang problematic internet use (Aboujaoude, 2010) dan perbandingan yang dilakukan terhadap kedua istilah tersebut (Yellowlees \& Marks, 2007), tulisan ini menggunakan nama variabel adiksi internet sebagai terjemahan dari internet addiction sedangkan penjelasan di dalam artikel secara bergantian digunakan istilah penggunaan internet berlebihan.

Permasalahan adiksi internet banyak dikeluhkan oleh orang tua karena anak remaja mereka mengalami kesulitan dalam mengontrol perilaku penggunaan internet. Keluhan para orang tua dan guru ini sangat beralasan karena fokus pikiran dari remaja selalu tertuju dan semakin hari semakin meningkat keinginannya untuk menggunakan internet. Jika pada awalnya mereka menggunakan internet hanya pada hari libur saja semakin hari kebutuhan ini meningkat dan semakin sulit untuk dikontrol apalagi pada saat remaja pengguna internet sedang mengalami tekanan psikologis, baik terkait permasalahan sekolah maupun personal. Internet dijadikan tempat melarikan diri dari suasana hati yang kurang menyenangkan.

Beberapa keluhan tersebut sesuai dengan gejala adiksi internet yaitu salience, mood modification, tolerance, withdrawal, conflict, dan relapse (Griffiths, 1995, 2005, 2010). Pendapat ini diperkuat juga oleh Widyanto \& McMurran (2004) bahwa terdapat enam dimensi internet addiction yaitu salience, penggunaan yang berlebihan, mengabaikan pekerjaan, antisipasi, kurangnya kontrol, dan mengabaikan kehidupan sosial. Pengguna internet yang mengalami adiksi ini tidak hanya meluangkan waktu yang berlebihan dengan internet namun lebih dari itu mereka juga mengabaikan tanggung jawab terkait kewajibannya.

Penelitian Gross et al. (2002) diikuti juga oleh (Cardak, 2013) dan (Wang et al., 2013) memperlihatkan bahwa pengabaian tanggung jawab terkait sekolah, keluarga, dan kehidupan sosial menjadi salah satu penyumbang rendahnya kesejahteraan psikologis remaja. Padahal Rathi dan Rastogi (2007) mengemukakan bahwa rendahnya kesejahteraan psikologis berdampak pada kualitas kebermaknaan hidup pada remaja dan beberapa variabel psikologis lain yang dibutuhkan untuk penyelesaian permasalahan kehidupan terkait karir dan kehidupan personal dan sosial yaitu efikasi diri yang tinggi dan kecerdasan emosi (Raihana, 2012). 
Social skills atau yang selanjutnya diterjemahkan dengan keterampilan sosial adalah kemampuan untuk melakukan interaksi sosial baik secara verbal maupun non verbal, dan pola pikir yang positif (Michelson, Sugai, Wood, \& Kazdin, 2013). Keterampilan sosial adalah salah satu aspek dari kecerdasan emosi yang dibutuhkan untuk berinteraksi sosial dalam rangka mengadopsi nilai moral dari budaya dan masyarakat (Salkind, 2006), termasuk di dalamnya mengasah interaksi dengan orang yang lebih tua, lebih muda, dan teman sebaya. Diskusi tentang bagaimana memulai percakapan, memberikan pujian dengan ikhlas, menjadi pendengar yang baik, berbagi informasi pribadi sewajarnya, dan menjadi percaya diri merupakan cara untuk meningkatkan keterampilan sosial (Michelson et al., 2013).

Fasilitasi pengembangan keterampilan sosial sangat dibutuhkan bagi remaja karena interaksi dengan orang lain dapat menjadi pembangun konsep diri yang positif bagi remaja (Ramdhani \& Martaniah, 1995). Dengan fakta bahwa sebagian besar remaja hingga dewasa awal kurang kompeten dalam hal keterampilan sosial (Shaffer, 2008), aktivitas mencari teman dan komunikasi melalui dunia maya kurang dapat mendukung upaya membangun ketrampilan sosial di dunia nyata (Mami \& Hatami-zad, 2014). Temuan lain juga menegaskan tentang keterkaitan antara aktivitas komunikasi di dunia maya dengan keterampilan sosial (Esen \& Gündoğdu, 2010; Majorsy, Kinasih, Andriani, \& Lisa, 2013) menegaskan tentang hal ini. Adiksi internet berkorelasi dengan rendahnya keterampilan sosial, bahkan mengarah kepada perilaku antisosial, keangkuhan, kesepian, kecemasan sosial (Dangkrueng, WannaUeumol, Yodming, \& Sirithongthaworn, 2013), dan kesejahteraan psikologis (Nair, Ravindranath, \& Thomas, 2013).

Hubungan positif antara keterampilan sosial dan kesejahteraan psikologis ini dijadikan dasar utama untuk menguji peran keterampilan sosial dan adiksi internet dalam memrediksi kesejahteraan psikologis. Secara spesifik, keterampilan sosial diposisikan sebagai mediator bagi hubungan kedua variabel tersebut karena apabila seorang remaja pengguna internet mempunyai keterampilan sosial yang lebih tinggi dihipotesiskan masih memungkinkan untuk mencapai kondisi sejahtera psikologis. Kondisi akan sangat berbeda apabila remaja pengguna internet kurang terampil sosial maka pencapaian taraf sejahtera secara psikologis mungkin akan lebih sulit. Dengan demikian, hipotesis dalam penelitian ini adalah keterampilan sosial merupakan mediator bagi hubungan adiksi internet dengan kesejahteraan psikologis.

\section{Metode}

\section{Partisipan}

Partisipan penelitian ini adalah 206 orang mahasiswa tahun pertama dan kedua di perguruan tinggi. Mereka terdiri dari $57,77 \%$ perempuan dan $42,23 \%$ lakilaki yang secara rutin menggunakan internet antara 5 hingga 10 jam per hari. $83,50 \%$ dari partisipan menggunakan laptop/komputer dan handphone dalam mengakses internet sedangkan sisanya mengakses salah satu saja.

\section{Alat ukur}

Data penelitian dikumpulkan dengan menggunakan 30 item Skala Kesejahteraan Psikologis (SKP) yang disusun oleh (Rachmayani \& Ramdhani, 2014a). SKP disusun berdasarkan enam aspek kesejah- 
teraan psikologi (Ryff \& Keyes, 1995) yaitu mandiri, penguasaan lingkungan, pertumbuhan pribadi, hubungan positif dengan orang lain, tujuan hidup, dan penerimaan diri. Beberapa contoh item yang digunakan adalah (1) 'keputusan saya biasanya tidak dipengaruhi oleh apa yang dilakukan orang lain' yang digunakan untuk mengungkap aspek mandiri, (2) 'saya cukup mahir mengelola beberapa tanggung jawab dalam kehidupan seharihari' yang mengungkap penguasaan lingkungan, dan (3) 'saya merasa telah berkembang banyak sebagai 'manusia' selama ini' yang digunakan untuk mengungkap aspek pertumbuhan pribadi. SKP yang disajikan dengan bentuk skala likert dengan 5 pilihan jawaban 'sangat tidak sesuai' hingga 'sangat sesuai' ini sudah diuji keandalannya $(\alpha=0,912)$ (Rachmayani \& Ramdhani, 2014b).

Keterampilan sosial diukur dengan 24 item dari Skala Keterampilan Sosial (SKS) yang tersusun dari tiga aspek pembentuk keterampilan sosial yaitu komunikasi verbal, non-verbal, dan faktor kognisi. Penyusunan SKS dilakukan dengan memodifikasi bahasa dan konteks dari SKS yang disusun oleh Ramdhani \& Martaniah (1995). Contoh item SKS, antara lain adalah (1) 'saya biasanya memulai percakapan dengan orang lain', untuk mengungkap aspek verbal, (2) 'berkeringat dingin bila harus berbicara di depan orang lain', yang mengungkap aspek verbal, dan (3) 'merasa yakin bahwa teman yang mengritik justru karena mereka menyenangi saya', mengungkap aspek kognisi. SKS yang disajikan dalam bentuk skala likert dengan 5 pilihan jawaban antara 'tidak pernah' hingga 'sangat sering' ini sudah diuji reliabilitasnya dengan $\alpha=0,89$ (Nugraini \& Ramdhani, 2015).

Adiksi internet diukur dengan 20 item Skala Adiksi Internet (SAI) yang disusun berdasarkan enam aspek dari adiksi internet yaitu pemusatan perhatian (salience), penggunaan berlebihan, pengabaian tanggung jawab, antisipasi, lemahnya kontrol, dan pengabaian kehidupan sosial (Young \& De Abreu, 2010). Contoh item yang digunakan di dalam penelitian ini antara lain (1) 'seberapa sering anda khawatir tentang betapa bosan, hampa, dan tidak gembiranya kehidupan tanpa internet', yang digunakan untuk mengungkap pemusatan perhatian, (2) seberapa sering prestasi belajar atau tugas sekolah anda terganggu karena terlalu banyak waktu yang dihabiskan untuk online?', untuk mengungkap penggunaan berlebihan. Keduapuluh item SAI ini disajikan dalam bentuk skala likert dengan lima pilihan jawaban antara 'tidak pernah' hingga 'sangat sering' dan telah diuji reliabilitasnya dengan $\alpha=0,9$.

Semua skala dan prosedur penelitian yang dilakukan sudah memenuhi tata etika penelitian yang ditetapkan oleh Fakultas Psikologi UGM. Peneliti tidak berada di dalam konflik atas kepentingan yang ada di dalam penelitian. Partisipan penelitian menjawab skala yang digunakan di dalam penelitian ini dengan sukarela tanpa diberi imbalan apapun.

\section{Analisis data}

Teknik analisis data yang digunakan dalam penelitian ini adalah analisis regresi dengan mediasi sederhana (simple mediation), yaitu analisis mediasi yang melibatkan hanya satu variabel mediator. Teknik analisis ini digunakan untuk mengetahui hubungan antara adiksi internet dan kesejahteraan psikologis, dengan keterampilan sosial sebagai mediatornya. Prosedur pengujian mediasi akan mengikuti prosedur yang dikemukakan oleh (Baron \& Kenny, 1986). Gambar 1 


\section{NUGRAINI \& RAMDHANI}

menjelaskan langkah analisis yang akan dilakukan. Software statistik yang digunakan untuk memperoleh hasil tersebut adalah SPSS (Statistical Package for Social Sciences) version 20.0 for windows.

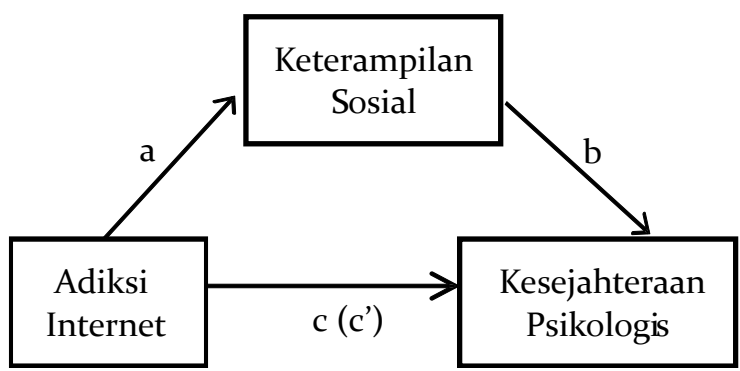

Gambar 1. Model analisis data penelitian (adaptasi dari Baron \& Kenny, 1986)

\section{Hasil}

Analisis tahap pertama dilakukan dengan analisis Regresi untuk menguji pemenuhan terhadap tiga kondisi yang disyaratkan (Baron \& Kenny, 1986). Kondisi pertama (c) untuk menguji bahwa adiksi internet merupakan prediktor yang signifikan dari kesejahteraan psikologis $t(204)=-2,04 ; \quad p<0,05$. Kondisi kedua (a) untuk menguji bahwa adiksi internet merupakan prediktor yang signifikan dari keterampilan sosial $t(204)=-4,86 ; \quad p<0,01$. Kondisi ketiga (c') untuk mengetahui peran adiksi internet dan keterampilan dalam memrediksi kesejahteraan psikologis yang menghasilakn $t(203)=-0,397$; $p>0,05$, nilai $p$ tidak signifikan membuktikan bahwa koefisien standar regresi antara adiksi internet dan kesejahteraan psiko- logis (c) menurun ketika dilakukan kontrol terhadap keterampilan sosial (c'). Dari hasil analisis tersebut dapat disimpulkan bahwa hubungan antara adiksi internet dengan kesejahteraan psikologis dimediasi oleh keterampilan sosial (hasil selengkapnya lihat Tabel 1).

Dengan melihat Tabel 1 dapat diketahui bahwa pengaruh adiksi internet terhadap kesejahteraan psikologis menurun ketika peran keterampilan sosial ikut diperhitungkan. Hasil analisis mediasi dengan prosedur PROCESS (Hayes, 2013) memperlihatkan hasil analisis yang tidak jauh berbeda dengan analisis yang tercantum di dalam Tabel 1. Sumbangan adiksi internet terhadap keterampilan sosial sebesar $10,38 \%\left(R^{2}=0,1038\right)$ lebih besar bila dibandingkan dengan sumbangan adiksi internet terhadap kesejahteraan psikologis yang hanya sebesar $2 \%\left(R^{2}=0,02\right)$.

Pengujian berikut memperlihatkan bahwa adiksi internet secara signifikan juga memengaruhi keterampilan sosial $(b=-0,34 ; t=4,51 ; p<0,01)$. Dari nilai $b$ yang negatif menunjukkan bahwa semakin tinggi adiksi internet maka semakin rendah keterampilan sosial individu, demikian pula sebaliknya.

Analisis berikutnya menguji model yang menggambarkan peran adiksi internet dan keterampilan sosial dalam memrediksi kesejahteraan psikologis memperlihatkan nilai $\mathrm{F}=11,24 ; \mathrm{p}<0,01$. Walaupun hasil ini signifikan namun ketika keteram-

Tabel 1.

Ringkasan hasil uji regresi antar variabel dengan prosedur Baron \& Kenny

\begin{tabular}{|c|c|c|c|c|c|c|}
\hline \multicolumn{2}{|c|}{ Variabel } & \multicolumn{2}{|c|}{$\begin{array}{c}\text { Unstandardized } \\
\text { Coeficients }\end{array}$} & \multirow{2}{*}{$\begin{array}{c}\text { Standardized } \\
\text { Coeficients }\end{array}$} & \multirow[t]{2}{*}{$\mathrm{t}$} & \multirow[t]{2}{*}{$p$} \\
\hline Independen & Dependen & $\mathrm{B}$ & Std. Error & & & \\
\hline $\mathrm{AI}$ & $\mathrm{KP}$ & $-0,18$ & 0,09 & $-0,14$ & $-2,04$ & 0,04 \\
\hline $\mathrm{AI}$ & KS & $-0,34$ & 0,07 & $-0,32$ & $-4,86$ & 0,00 \\
\hline $\mathrm{AI}^{*} \mathrm{KS}$ & $\mathrm{KP}$ & $-0,03$ & 0,09 & $-0,03$ & $-0,40$ & 0,69 \\
\hline
\end{tabular}

Keterangan: $\mathrm{KP}=$ Kesejahteraan Psikologis; $\mathrm{KS}=$ Keterampilan Sosial; AI= Adiksi Internet 
pilan sosial ikut diperhitungkan, diperoleh hasil bahwa adiksi internet bukan prediktor kesejahteraan psikologis $(b=-0,03, t=-$ $0,38, \mathrm{p}>0,05)$. Di dalam model ini, peran keterampilan sosial cukup besar terhadap kesejahteraan psikologis $(b=0,42, t=4,11$, $\mathrm{p}<0,01)$. Dari hasil analisis ini diperoleh koefisien determinasi $\mathrm{R}^{2}$ sebesar 0,1323 menunjukkan bahwa variabel keterampilan sosial dan adiksi internet memberikan sumbangan sebesar $13,23 \%$ terhadap kesejahteraan psikologis. Dengan memperhatikan nilai $b$ dari adiksi internet yang negatif dan nilai $b$ dari keterampilan sosial yang positif maka disimpulkan bahwa keterampilan sosial merupakan mediator dari hubungan adiksi internet dengan kesejahteraan psikologis. Dengan kata lain, tingginya adiksi internet akan semakin merendahkan kesejahteraan psikologis pada saat skor keterampilan sosial rendah. Namun, adiksi internet yang tinggi ini belum tentu merendahkan kesejahteraan psikologis bila keterampilan sosial yang dimiliki individu cukup tinggi.

\section{Diskusi}

Hasil analisis yang telah dilakukan, baik dengan prosedur (Baron \& Kenny, 1986) maupun dengan prosedur Process (Hayes, 2013) menunjukkan bahwa data yang diperoleh melalui penelitian ini sesuai dengan hipotesis penelitian yang diajukan. Hubungan penggunaan internet dengan kesejahteraan psikologis terbukti dimediasi oleh keterampilan sosial. Ketika analisis dilakukan tanpa mempertimbangkan keterampilan sosial, penggunaan internet yang tinggi secara signifikan menjadi prediktor dari rendahnya kesejahteraan psikologis. Namun, ketika hubungan antara kedua variabel ini dilakukan dengan memperhitungkan peran keterampilan sosial, hasil yang diperoleh memperlihatkan bahwa pengaruh penggunaan internet tidak lagi signifikan terhadap kesejahteraan psikologis. Dengan kata lain pengaruh negatif adiksi internet terhadap kesejahteraan psikologis dapat melemah atau menguat tergantung kepada tinggi atau rendahnya skor keterampilan sosial individu.

Hasil analisis penelitian ini sesuai dengan beberapa penelitian terdahulu yang membuktikan bahwa penggunaan internet yang tinggi berhubungan dengan rendahnya keterampilan sosial (Jenaabadi \& Fatehrad, 2015; Karimzadeh, 2015). Hal ini dapat terjadi karena semakin banyak waktu yang dihabiskan individu dengan internet maka semakin berkurang kesempatan mereka untuk menjalin hubungan dengan orang-orang di sekitarnya sehingga waktu yang untuk mengasah keterampilan berhubungan dengan orang lainpun menjadi semakin terbatas.

Keterampilan sosial yang tinggi menjadi kunci bagi terciptanya kesejahteraan psikologis. Beberapa riset sudah melaporkan kuatnya peran keterampilan sosial dalam menentukan kesejahteraan psikologis (Leme, Del Prette, \& Coimbra, 2015; Muse, 2014; Nair et al., 2013). Keterampilan sosial memberi peluang kepada individu mengembangkan hubungan yang positif dengan orang-orang di sekitarnya sehingga individu mampu menguasai lingkungannya dengan lebih baik. Pola pikir positif dari seorang yang terampil sosial memberikan sumbangan positif terhadap tumbuhnya kemandirian dan keberanian dalam menentukan tujuan hidup. Kekuatan kognisi positif yang dimiliki oleh seorang yang terampil sosial ini juga sangat membantu individu yang mengalami masalah dengan harga diri (Ramdhani \& Martaniah, 1995). Padahal, menurut riset yang dilakukan Zhang et al. (2015), individu yang mengalami adiksi 


\section{NUGRAINI \& RAMDHANI}

terhadap internet ini sebagian mengalami permasalahan dengan harga diri.

Hasil penelitian ini menunjukkan bahwa keterampilan sosial berperan sangat penting dalam menentukan apakah individu yang menggunakan internet berlebihan akan mendapatkan atau tidak mendapatkan kondisi sejahtera secara psikologis. Pada individu yang memiliki keterampilan sosial tinggi, nampaknya internet digunakan untuk berbagai tujuan yang masih dapat dipertanggung jawabkan. Sebagaimana riset yang dilakukan Chen (2012) bahwa penggunaan internet untuk tujuan mempererat hubungan sosial justru dapat meningkatkan kesejateraan psikologis.

Hasil analisis penelitian yang dilakukan ini juga nampaknya menyetujui temuan Chen tersebut karena tercapai atau tidaknya kondisi kesejahteraan psikologis pada individu yang menggunakan internet tinggi sangat tergantung kepada keterampilan sosial. Bagi individu yang mempunyai keterampilan sosial tinggi, membangun hubungan sosial merupakan aktivitas yang menyenangkan sehingga media sosial berbasis internet dimanfaatkan untuk memelihara hubungan sosial yang sudah terjalin sehingga kesejahteraan psikologis dapat tetap terpelihara. Individu pengguna internet yang mempunyai keterampilan sosial tinggi tetap dapat merasakan kenyaman sosial dan terbebas dari rasa kesepian (Cardak, 2013). Sebaliknya, individu yang kurang terampil sosial cenderung mengalami masalah terkait emosi perilaku, misalnya cenderung kesepian, memiliki nilai hidup yang menyimpang, dan enggan mengembangkan keterampilan sosial (Engelberg \& Sjöberg, 2004), antisosial, komunikasi agresif (Rezaei, Esmaili, \& Khademi, 2014), mengalami kecemasan, dan stres (Azher et al., 2014).
Hasil riset ini membuktikan hipotesis bahwa keterampilan sosial merupakan variabel penting dalam menentukan kondisi kesejahteraan psikologis bagi individu yang sering menggunakan internet. Dengan persentase sumbangan variabel perilaku menggunakan internet dan keterampilan sosial yang tidak terlalu tinggi $(13,23 \%)$, penelitian selanjutnya sangat dibutuhkan untuk mengungkap peran dari variabel lain dalam menentukan tingkat kesejahteraan psikologis individu yang sering menggunakan internet, terutama media sosial.

\section{Kesimpulan}

Keterampilan sosial merupakan variabel yang penting untuk terus diperhatikan dan dikembangkan apabila individu pengguna Internet ingin tetap memperoleh atau mempertahankan kehidupan yang sejahtera secara psikologis. Semakin meningkatnya penggunaan Internet di dalam kehidupan sehari-hari, terutama di kalangan generasi muda, tantangan semakin mendesak bagi para pendidik untuk lebih banyak memfasilitasi program pendidikan yang dapat dijadikan stimulus pengembangan keterampilan sosial.

\section{Saran}

Beberapa inisiasi pengembangan keterampilan sosial yang sudah dilaksanakan perlu dipertahankan bahkan ditingkatkan. Contoh kegiatan yang sudah ada misalnya kelompok-kelompok teman sebaya, aktivitas ekstrakurikuler yang berisi kegiatan kerja sama kelompok bagi para (maha)siswa di sekolah, pramuka, dan lain-lain. Kegiatan ini tentu saja perlu ditunjang dengan peningkatan fasilitas yang memungkinkan masyarakat saling 
berjumpa berinteraksi satu sama lain. Dari sisi profesi psikologi, program-program intervensi primer maupun sekunder perlu dijadikan fokus perhatian utama untuk mencegah meningkatnya dampak lain dari perasaan tidak sejahtera secara psikologis yang dialami individu.

\section{Kepustakaan}

Aboujaoude, E. (2010). Problematic internet use: An overview. World Psychiatry, 9(2), 85-90. http://dx.doi.org/ 10.1002/j.2051-5545.2010.tb00278.x

Azher, M., Khan, R. B., Salim, M., Bilal, M., Hussain, A., \& Haseeb, M. (2014). The relationship between internet addiction and anxiety among students of University of Sargodha. International Journal of Humanities and Social Science, 4(1), 288-293.

Baron, R. M., \& Kenny, D. A. (1986). The moderator-mediator variable distinction in social psychological research: conceptual, strategic, and statistical considerations. Journal of Personality and Social Psychology, 51(6), 11731182. http://dx.doi.org/10.1037/00223514.51.6.1173

Block, J. J. (2008). Issues for DSM-V: Internet addiction. http://dx.doi.org/ 10.1176/appi.ajp.2007.07101556

Cardak, M. (2013). Psychological wellbeing and Internet addiction among university students. TOJET: The Turkish Online Journal of Educational Technology, 12(3).

Chen, S.-K. (2012). Internet use and psychological well-being among college students: A latent profile approach. Computers in Human Behavior, 28(6), 2219-2226. http:// dx.doi.org/10.1016/j.chb.2012.06.029

Dangkrueng, S., WannaUeumol, T.,
Yodming, P., \& Sirithongthaworn, S. (2013). Relationships between Internet Addiction and Loneliness, and Internet Addiction and Teenage Social Skills: A Case Study of Mathayom Suksa Students in the Northern Region. International Journal of Child Devlelopment and Mental Health, 1(2), 26-30.

El Khouli, M. (2013). The most important negative aspects of using social networking affecting the family stability in Abu Dhabi-a pilot study. International Journal of Engineering and Technology, 5(1), 85. http://dx.doi.org/ 10.7763/IJET.2013.V5.517

Engelberg, E., \& Sjöberg, L. (2004). Internet use, social skills, and adjustment. CyberPsychology \& Behavior, 7(1), 41$47 . \quad$ http://dx.doi.org/10.1089/ 109493104322820101

Esen, B. K., Aktas, E., \& Tuncer, I. (2013). An analysis of university students' Internet use in relation to loneliness and social self-efficacy. Procedia-Social and Behavioral Sciences, 84, 1504-1508. http://dx.doi.org/10.1016/j.sbspro.2013 .06 .780

Esen, B. K., \& Gündoğdu, M. (2010). The relationship between internet addiction, peer pressure and perceived social support among adolescents. The International Journal of Educational Researchers, 2(1), 29-36.

Griffiths, M. (1995). Technological addictions. In Clinical Psychology Forum (p. 14). Division Of Clinical Psychology Of The British Psychol Soc.

Griffiths, M. (2005). A "components" model of addiction within a biopsychosocial framework. Journal of Substance Use, 10(4), 191-197. http:// dx.doi.org/10.108014659890500114359 
Griffiths, M. (2010). Internet abuse and internet addiction in the workplace. Journal of Workplace Learning, 22(7), 463-472. http://dx.doi.org/10.1108/ 13665621011071127

Griffiths, M., \& Wood, R. T. A. (2000). Risk factors in adolescence: The case of gambling, videogame playing, and the Internet. Journal of Gambling Studies, 16(2-3), 199-225.

Gross, E. F., Juvonen, J., \& Gable, S. L. (2002). Internet use and well-being in adolescence. Journal of Social Issues, 58(1), 75-90. http://dx.doi.org/10.1111/ 1540-4560.00249

Hayes, A. F. (2013). Introduction to mediation, moderation, and conditional process analysis: A regression-based approach. Guilford Press.

Jenaabadi, H., \& Fatehrad, G. (2015). A Study of the Relationship between Internet Dependence and Social Skills of Students of Medical Sciences. Modern Applied Science, 9(8), 49.

Karimzadeh, N. (2015). Investigating the Relationship between Internet Addiction and Strengthening Students' Social Skills. Educational Research and Reviews, 10(15), 2146-2152. http:// dx.doi.org/10.5897/ERR2015.2338

Leme, V. B. R., Del Prette, Z. A. P., \& Coimbra, S. (2015). Social skills, social support and well-being in adolescents of different family configurations. Paidéia (Ribeirão Preto), 25(60), 9-17. http://dx.doi.org/10.1590/198243272560201503

Majorsy, U., Kinasih, A. D., Andriani, I., \& Lisa, W. (2013). Hubungan antara Keterampilan Sosial dan Kecanduan Situs Jejaring Sosial pada masa Dewasa Awal. Proceeding PESAT (Psikologi, Ekonomi, Sastra, Arsitektur E Teknik Sipil), Bandung, 5.
Mami, S., \& Hatami-zad, A. (2014). Investigating the effect of Internet Addiction on Social Skills and in High School Students ' Achievement, International J. Soc. Sci. E Education, 4, 56-61.

Michelson, L., Sugai, D. P., Wood, R. P., \& Kazdin, A. E. (2013). Social skills assessment and training with children: An empirically based handbook. Springer Science \& Business Media.

Muse, Y. (2014). Social Skills and Psychological Wellbeing of Adolescents in Monogamous and Polygamous Marriage Structures: The Case of Sidama Community.

Nair, R., Ravindranath, S., \& Thomas, J. (2013). Can Social Skills Predict Wellbeing. An Exploration. European Academic Research, 1(5), 712-720.

Nugraini, I., \& Ramdhani, N. (2015). Keterampilan Sosial sebagai Mediator antara Hubungan Kecanduan Internet dan Kesejahteraan Psikologis pada Remaja. Skripsi, tidak diterbitkan. Universitas Gadjah Mada.

Rachmayani, D., \& Ramdhani, N. (2014a). Adaptasi Bahasa dan Budaya Skala Psychological Wellbeing. In Seminar Nasional Psikometri (pp. 253-268). Universitas Muhammadiyah Surakarta.

Rachmayani, D., \& Ramdhani, N. (2014b). Literasi Digital sebagai Mediator Hubungan antara Ciri Kepribadian Extraversion, Neuroticism, dan Openness to Experience dengan Psychological Wellbeing pada Remaja Pengguna Teknologi. Universitas Gadjah Mada.

Raihana, G. F. H. (2012). Cloud ERP-a solution model. International Journal of Computer Science and Information Technology \& Security, 2(1), 76-79. 
Ramdhani, N., \& Martaniah, S. M. (1995). Pelatihan keterampilan sosial pada mahasiswa yang sulit bergaul Social skills training on shy-socially isolated students. Berkala Penelitian Pasca Sarjana, 8(1995).

Rathi, N., \& Rastogi, R. (2007). Meaning in life and psychological well-being in pre-adolescents and adolescents. Journal of the Indian Academy of Applied Psychology, 33(1), 31-38.

Rezaei, S., Esmaili, A., \& Khademi, A. (2014). The Expectation of Social Skills Based on Students' Internet Addiction of Azad University, Brunch of Urmia, Iran. Journal of Psychology \& Behavioral Studies, 2(6), 225-234.

Rideout, V. J., Foehr, U. G., \& Roberts, D. F. (2010). Generation M [superscript 2]: Media in the Lives of 8-to 18-YearOlds. Henry J. Kaiser Family Foundation.

Rodman, G., \& Fry, K. G. (2009). Communication technology and psychological wellbeing: Yin, Yang, and the golden mean of media effects. In Y. Amichai-Hamburger (Ed.), Technology and Psychological Well-Being (pp. 933). New York: Cambridge University Press.

Ryff, C. D., \& Keyes, C. L. M. (1995). The structure of psychological well-being revisited. Journal of Personality and Social Psychology, 69(4), 719.

Salkind, N. J. (2006). Ecological Theory. NJ Salkind, Encyclopedia of Human Development, 438-440.

Shaffer, D. (2008). Social and personality development. Nelson Education.

Shapira, N. A., Lessig, M. C., Goldsmith, T. D., Szabo, S. T., Lazoritz, M., Gold, M. S., \& Stein, D. J. (2003). Problematic internet use: proposed classification and diagnostic criteria. Depression and Anxiety, 17(4), 207-216. http:// dx.doi.org/10.1002/da.10094

Wahid, F., Ramdhani, N., \& Wiradhany, W. (2014). More gaining and less gaming? The internet use in Indonesia after one decade. In Recent Trends in Social and Behaviour Sciences: Proceedings of the International Congress on Interdisciplinary Behaviour and Social Sciences 2013 (p. 217). CRC Press.

Wang, L., Luo, J., Bai, Y., Kong, J., Luo, J., Gao, W., \& Sun, X. (2013). Internet addiction of adolescents in China: Prevalence, predictors, and association with well-being. Addiction Research \& Theory, 21(1), 62-69.

Widyanto, L., \& McMurran, M. (2004). The psychometric properties of the internet addiction test. Cyber Psychology \& Behavior, 7(4), 443-450.

Yellowlees, P. M., \& Marks, S. (2007). Problematic Internet use or Internet addiction? Computers in Human Behavior, 23(3), 1447-1453.

Young, K. S. (2004). Internet addiction: A new clinical phenomenon and its consequences. American Behavioral Scientist, 48(4), 402-415.

Young, K. S., \& De Abreu, C. N. (2010). Internet addiction: A handbook and guide to evaluation and treatment. John Wiley \& Sons.

Zhang, Y., Mei, S., Li, L., Chai, J., Li, J., \& $\mathrm{Du}, \mathrm{H}$. (2015). The relationship between impulsivity and internet addiction in Chinese college students: A moderated mediation analysis of meaning in life and self-esteem. PloS One, 10(7), e0131597. http:// dx.doi.org/10.1371/journal.pone.01315 97 